\title{
Verbal and Nonverbal Factors Influencing the Success of Da'wah Communication By Ustadz Abdul Somad
}

Waizul Qarni, Mhd. Syahnan, Isnaini Harahap, Sahkholid Nasution, and Rahmah Fithriani

Universitas Islam Negeri Sumatera Utara (UIN SU), Medan, Indonesia

\section{Abstract}

Da'wah is the term used to refer to the process of spreading information about Islam by a da'l (a Muslim communicator). Indonesia, as the country with the biggest Muslim population in the world has produced a large number of da'l who gain popularity in either, local, national, or international scale. Ustadz Abdul Somad is one among the most popular da'l from Indonesia who in the last few years has attracted audience across various social economic, educational, and political backgrounds. Driven by the popularity gained by Abdul Somad which outruns most other da'l in Indonesia, this study aims to investigate the factors influencing the success of his

Corresponding Author: Waizul Qarni

waizulqarni@uinsu.ac.id

Received: 1 July 2019

Accepted: 18 July 2019

Published: 31 July 2019

Publishing services provided by Knowledge E

(c) Waizul Qarni et al. This article is distributed under the terms of the Creative Commons

Attribution License, which permits unrestricted use and redistribution provided that the original author and source are credited.

Selection and Peer-review under the responsibility of the AICLL 2019 Conference Committee.

\section{G OPEN ACCESS} da'wah communication. This study applied a descriptive qualitative approach using documentation and interview as the instruments of data collection. The findings show that there are two main factors behind the success of his da'wah communication, First, the verbal factors which include comprehensive reference and the language choice. Second, the nonverbal one, which in this case is the use of various platforms for da'wah dissemination.

Keywords: Communication, Da'wah, Verbal, Nonverbal

\section{Introduction}

Da'wah is an effort to invite people to always hold on to Islamic teachings to gain happiness in this life and hereafter (Jafar, 2010). Similar to this definition, Mubarok (1999) defines da'wah as a way to invite people to the right path of Islam so that they can live happily in the world and hereafter. Someone who does the act of da'wah is called as "Da'l" or Islamic preachers. They have deepened their understanding of Islamic teachings and are committed to share their knowledge to others. For this reason, Islamic preachers should have good communication skills to communicate effectively in front of their audience (mad'u). Da'wah can be categorized as successful when the content of Da'wah is followed by the listeners. In other words, da'wah aims to influence people to act in accordance with what the Da'l conveys in his da'wah. 
Da'wah is very important for Muslims since it is a way to help Muslims understand their religion better, especially the Muslims in Indonesia as a country with the highest Muslim population in the world. Approximately, in 2015, Islam has 1.8 billion adherents, making up about $24.1 \%$ of the world population. Muslim population in Indonesia is the largest in the world, with approximately 225 million Muslims, and 87.2\% of Indonesian population identifying themselves as Muslim in 2010 (BPS, 2010). Despite the number of Muslims in Indonesia outweighs the percentage of other religions, Indonesia is not an Islamic state, instead a secular state whose government officially recognizes six formal religions (Martin, 2004). This fact is one contributing factor to the establishment of Islamic boarding schools that produced Islamic preachers in Indonesia.

Islamic preachers (Da') have played important roles in spreading Islam in Indonesia, for example; Walisongo (the nine Islamic preachers). In the $14^{\text {th }}$ century, Walisongo spread the Islamic teachings in East Java, Central Java, and West Java (Ricklefs, 1991). They encouraged the local people to adhere Islam without any force. Today, in this advanced technological era, da'wah can be done without face to face meeting. With the presence of social networking sites and social media, many Islamic preachers do their da'wah on Instagram, Facebook, and twitter or YouTube, and they are well-known in local, national or international scale. Some of them are; Yusuf Mansur, Gus Mus, Aa Gym, Arifin Ilham, Syekh Ali Jaber, Anwar Zahid, Ulil Absar Abdalla, Hanan Attaki, and Abdul Somad.

Among these Da'ls, who are also called as Ustadz in Indonesia, in the past few years, Ustadz Abdul Somad (UAS) has gained more popularity compared to other Da'ls. It can be seen from the number of his da'wah subscribers on YouTube and followers on Instagram. Since finishing his study in 2002 from the University of Al Azhar, Cairo, UAS started to gain public attention since he uploaded his da'wah videos on YouTube and Instagram. Up to this point, UAS has 7.2 million followers on Instagram (TribunTimur.com, 2019) and 38.7 million people who watched his da'wah videos on YouTube. In addition, he can attract the audience of different social economic, educational, and political backgrounds.

Related to this phenomenon, this current study tries to investigate the factors influencing the success of UAS's da'wah communication. Of course, several researches related to da'wah have been conducted in Indonesia. However, none of them discusses about the factors contributing to the success of da'wah in Indonesia. A study conducted by Aini and Husna (2018) about the type of da'wah communication used by da'wah workers in conveying the message of Islam to the aboriginals shows that to develop effective communication, the da'wah workers do not only apply verbal communication, 
but also non-verbal communication to introduce the concept of Islam to the aborigines. In Indonesia, Murthado (2017) has studied about the empowerment of social media for da'wah in Medan, but he did not discuss about the factors contributing to the success of da'wah. Thus, the study related to factors contributing to the success of da'wah dissemination is considered important since the results of this study will be beneficial to be used as a reference for other Islamic preachers in Indonesia. By understanding the contributing factors, other Islamic preachers will have better communication skills in delivering their da'wah successfully. Thus, it is expected that the listeners follow the content of da'wah and behave in the right path of Islam and be happy in this world and hereafter.

\section{Literature Review}

\subsection{Da'wah and communication}

Literally, da'wah means "issuing a summon" or "making an invitation". It functions to invite people to understand Islam through dialogue (Online, 2018). A Muslim who has deep understanding about Islamic teachings and performs the da'wah is called as Da' (Islamic preachers). However, a Muslim whose profession is not a da'l can also share his understanding about Islamic teachings, for example; a father who reminded his son about the obligation of Friday prayer for men in Islam. Even though he might work as an entrepreneur, he should not wait for a da'l to teach his son about Islam.

Da'wah involves communication which encourages social interaction between $d a^{\prime} l$ and his audience (mad'u) (Mubarok, 1999). For this reason, a da'l should have a wide range of knowledge related to Islamic teachings, the social behavior of human beings, and the socio-cultural environment where they live. It is important to make sure that the message of da'wah is conveyed successfully since nowadays' society should find the solution to overcome the challenge of communication intensity (Ekayati \& Saniaty, 2018).

To achieve this goal, in the Qur'an An-Nahl: 125, it is stated that:

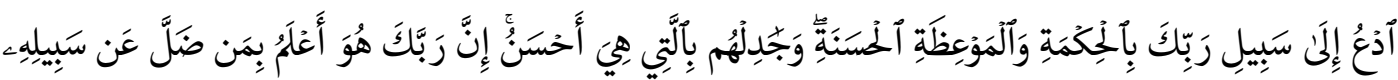

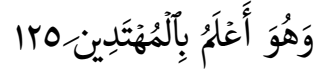

It means: "Call to the way of your Lord with wisdom and goodly exhortation and have disputations with them in the best manner; surely your Lord best knows those who go astray from His path, and He knows best those who follow the right way." 
From the verse of the Qur'an above, it can be understood that "wisdom", "good instruction" and "arguing well" are three things needed in da'wah.

\subsection{Factors contributing to the success of Da'wah}

It is stated that da'wah will be delivered successfully if the message contained in da'wah is fully explained by the Da'l (Mubarok, 1999). The success of da'wah can also be seen if Mad'u (the audience) do the message of da'wah conveyed by the da'l. For instance, when a $d a^{\prime}$ l reminds the importance of performing five-time prayer a day in Islam, and the people who listen to his da'wah (the Mad'u) perform the message, it means the da'wah has been successfully communicated.

Rachmat (1986) mentions several things that make a success da'wah:

1. The audiences understand the message of the da'wah.

2. The audiences are happy with the knowledge they learned from a da'wah.

3. The da'wah changes the audiences' behavior to be better than before, for example; being ignorant to be more sympathy.

4. The da'wah results in a good relationship between a da'l and his audiences, for example; from a teacher, becoming a friend.

5. The da'wah improves the audiences' action toward their daily life, for example; being perplexed to perform prayer to be more diligent to do it.

Besides these improvements, other factors contributing to a success of da'wah are verbal and non-verbal communication. Since communicating skill plays an important role in da'wah, the factors that influence the success of communication also apply to the success of da'wah (proselytizing). In their article, Aini and Husna (2018) explain that da'l should choose an appropriate type of communication to perform the da'wah. They also add that verbal communication might involve the use of certain language medium to convey the message of da'wah to the recipient through verbal medium, such as; public speaking, sermon, dialogue and discussion. They furthermore propose the procedures of verbal communication, namely; the topic of conversation should be about something good and beneficial, the communicator should avoid mentioning unbeneficial things, he is truthful, does not expose others' weakness, does not say bad things and look down on others, and he observes the ethics when differing in views with others (Aini \& Husna, 2018). Meanwhile, the non-verbal communication is related to facial expression, eyes 
and body movement which could have a big influence in communication (Mc Auley, 1988).

\subsection{Ustadz Abdul Somad (UAS)}

As a country with a higher number of Muslims, Indonesia has many Islamic preachers who are well-known in national and international scale. Ustadz Abdul Somad, popularly called UAS, is one among Islamic preachers in Indonesia who have attracted peoples attention in the past few years. Abdul Somad Batubara (born May, 1977) is an Indonesian Islamic preacher and Ulama from Asahan, North Sumatra. He is known for his lectures on various religious issues, especially regarding hadith studies and Islamic jurisprudence. $\mathrm{He}$ is currently on service as a lecturer at the State Islamic University of Sultan Syarif Kasim II (UIN SUSKA) Riau.

Ustadz Abdul Somad went through his elementary education at Al-Washliyah. Then, he continued his education at Mu'alimin al-Washliyah Medan. In 1993, he studied at Nurul Falah, and completed it in 1996. In 1998, Ustadz Abdul Somad was among 100 students who received scholarships granted by the Egyptian government for Indonesian students studying at Al Azhar University. In 2004, the Moroccan government provided him scholarship for post-graduate education at Dar al Hadith al Hasaniyyah Institute which annually receives 20 students, consisted of 15 Moroccans and five foreigners.

\section{Research Method}

This study applied a descriptive qualitative approach using documentation and interview as the instrument of data collection. The main data source for this study was the video of UAS's da'wah published on YouTube (www.youtube.com). In addition, 4 people (2 men and 2 women) were invited as the participants of the study for interview session. The four participants were selected based on the criterion of YouTube subscribers who watch UAS da'wah video regularly. The data gained from the interview were analyzed using content analysis. Meanwhile, the data from documentation were analyzed using document analysis technique as suggested by Miles, Huberman, and Saldana (2014).

\section{Result and Discussion}

After analyzing the data, the results indicate that there are two main factors contributing to the success of Ustadz Abdul Somad's da'wah, namely; verbal and non-verbal factors. 
The verbal factors include comprehensive reference and the language choice. Meanwhile, the non-verbal factor is the use of various platforms for da'wah dissemination.

\subsection{Verbal factors}

The popularity of Ustadz Abdul Somad is supported by two verbal factors; (1) the humors and playful words he likes to use when conveying his da'wah in front of the audience (mad'u), and (2) his rigorous explanation based the Qur'an and Hadith and his ability to link his explanation to current situation and the life of recipients (mad'u) with Islamic teachings in order to create friendly environment in his da'wah. With the use of unique rhetoric and humor that attract layman and political leader, his humor and deep knowledge have influenced people of different social backgrounds to feel happy with the knowledge they got from his da'wah, and it is one of several signs for a success of da'wah dissemination explained by Rachmat (1986).

In delivering his da'wah, Ustadz Abdul Somad disseminates the Islamic teachings, provides solution and answer to the questions asked by his audience in a way that can be understood by his audience. For examples, when talking in front of Acehnese, Ustadz Abdul Somad speaks Aceh language, when given opportunity to talk in front of the House of Representatives; he used playful words and humors related to the context of the House of Representatives. Thus, it proves that Ustadz Abdul Somad could use appropriate type of communication to perform his da'wah. Moreover, everything he says is truthful as he always supports his explanation with the Qur'anic verses and shahih hadith. He never says bad things or looks down on others, and he also respects other people's view.

This finding is in line with the statements given by the interviewed participants who were asked about UAS' da'wah;

"I like watching UAS' da'wah because he conveys his da'wah in a fun way. It's like watching a stand-up comedy show [laughing]." (Participant 1, a man)

Another participant also mentioned that:

"I like watching UAS' da'wah because he explains rigorously by referring to the Qur'an and Hadith, and it makes me more confident in practicing Islamic teachings." (Participant 2, a man) 


\subsection{Non-verbal factors}

The personality of Ustadz Abdul Somad himself also supports the success of his da'wah. $\mathrm{He}$ is simple and ordinary if compared to other Islamic preachers. Another factor that contributes to the success of Ustadz Abdul Somad in influencing people to perform the Islamic teachings through his da'wah is the presence of technology. What makes him different to other Islamic preachers who also gained popularity in the past, like K.H. Zainuddin M.Z. is because today, Ustadz Abdul Somad has access to SNS and internet that have dominated the life of people in Indonesia. Using this opportunity, the popularization of social media, Ustadz Abdul Somad tries to reach more people of different ages and professions by broadcasting his da'wah through YouTube channel and other social media on Internet, and it results in his national fame in Indonesia.

The findings above are in accordance with the statements given by the participants interviewed:

'UAS' da'wah is interesting to watch. I like it because I can listen to his da'wah from YouTube while I am cooking in the kitchen." (Participant 3, a woman)

Another participant also mentions that:

"Previously I did not know UAS, but because I often saw his da'wah on Instagram, Facebook and YouTube, I have come to like it and have started to watch his da'wah since then." (Participant 2, a man)

\section{Conclusion}

As a country with a large number of Muslims, Indonesia has established many Islamic institutions that produce great da'ls. Among those da'ls, Ustadz Abdul Somad can attract more people to listen and to watch his da'wah if compared to other Islamic preachers. This study has investigated the factors influencing the success of da'wah by Ustadz Abdul Somad by analyzing the da'wah videos he uploaded on YouTube. After analyzing the data, the result indicates that Ustadz Abdul Somad is famous due to the verbal and non-verbal factors. The verbal factors are the humors and playful words he likes to use in his da'wah, his comprehensive understanding of the Qur'an and Hadith which can provide clear answer to the questions asked by people of this era, and the appropriate words he chooses for his audience in delivering the da'wah. The non-verbal factors include the use of various platforms in disseminating da'wah, such as; YouTube 
channel and Instagram, and also the simple ordinary and cheerful personality of Ustadz Abdul Somad which makes him closer to his audience, and the body language and humorous facial expression he uses in front of his audience. The findings of this study are expected to be beneficial for young $d a^{\prime} / s$ so that they will become more prepared in spreading Islamic teaching in national and international scale.

[1] Aini, Z. B., \& Husna, Sad, N. D. (2018). Types of da'wah communication used By da'wah workers in conveying the message of Islam to the Aboriginals', The Online Journal of Science and Technology, 8(2), 129-138.

[2] BPS (2010, May 15) Penduduk Menurut Wilayah dan Agama yang Dianut. Available at: http://sp2010.bps.go.id/index.php/site/tabel?tid=321\&wid=0 (Accessed: 30 April 2019).

[3] Ekayati, R. \& Saniaty, D. (2018) Communication strategies used by tourist guides: A case study at Bukit Lawang. In the 1st Annual International Conference on Language and Literature, KnE Social Sciences, pp. 639-649). DOI 10.18502/kss.v3i4.1983.

[4] Jafar, I. (2010). Tujuan dakwah dalam perspektif All-Qur'an: Mempertajam fokus dan orientasi dakwah Ilahi, MIQOT Jurnal IImu-IImu Keis/aman, 34(2). Available at: http: //jurnalmiqotojs.uinsu.ac.id/index.php/jurnalmiqot/article/view/208/200.

[5] Martin, R. C. (2004) Encyclopedia of Islam and the Muslim World Vol. 2 M-Z. Macmillan.

[6] Mc Auley, G. J. (1988) Komunikasi Antara Manusia. Terj. Moh. Safar Hashim \& Fatimah Yusooff. Kuala Lumpur: Dewan Bahasa dan Pustaka.

[7] Miles, M. B., Huberman, A. M. \& Saldana, J. (2014). Qualitative data analysis: A methods sourcebook. Thousand Oaks, CA: Sage.

[8] Mubarok, A. (1999) Psikologi Dakwah. Jakarta: Penerbit Pustaka Firdaus.

[9] Murthado, A. (2017). The empowerment of social media for da'wah in Medan city', IOSR Journal of Humanities and Social Science (IOSR-JHSS), 22(4), 86-93.

[10] Online, O. I. S. (2018) Dakwah (Malaysia), 2 November. Available at: http://www. oxfordislamicstudies.com/article/opr/t125/e480 (Accessed: 30 April 2019).

[11] Rachmat, J. (1986) Psikologi Komunikasi. Bandung: Remaja Karya.

[12] Ricklefs, M. C. (1991) A History of Modern Indonesia since c.1300. London: Macmillan.

[13] Tribun-Timur.com (2019) Instagram Ustadz Abdul Somad Punya 7.2 Juta Follower, Berikut Daftar 108 IG Di-Follow UAS, Ada IG-mu?, 1 February. Available at: http://makassar.tribunnews.com/2019/02/01/instagram-ustaz-abdul-somad-punya72-juta-follower-berikut-daftar-108-ig-di-follow-uas-ada-ig-mu (Accessed: 30 April 
2019). 